\title{
Professional women and maternity transition: Guidelines for maternity coaching in organisations
}

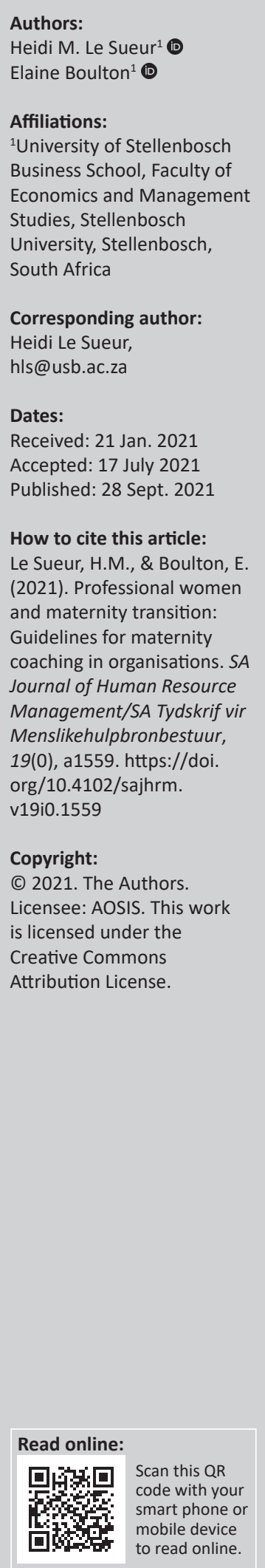

Orientation and research purpose: There is a need to explore the role of maternity coaching in supporting and retaining professional women in South African organisations. Therefore, this study investigated the experiences of professional women during their maternity transition into working mothers and explored how maternity coaching can be used as a strategic intervention to support these women.

Research design, approach and methodology: A qualitative inductive methodological approach was followed to gain an in-depth understanding of maternity coaching. The research strategy was cross-sectional and multi-perspective, consisting of 13 participants from 4 professional groups.

Main findings: The findings emphasise that maternity coaching can play a positive role in assisting both working women and organisations to successfully navigate the maternity transition phase. Through the findings, it was established why maternity coaching is needed as a mechanism of support, how maternity coaching should be implemented and what should be included in the coaching conversations.

Practical managerial implications: This article provides a Maternity Transition Coaching Model with guidelines and recommendations for different professional groups in any organisation where maternity transition is experienced. The implications of this study are how maternity coaching can be implemented as a tool in dealing with retention of professional women during maternity transition and to increase gender diversity at the senior organisational level.

Contribution: The body of knowledge contributes to understanding the role of maternity coaching as an emerging form of transition coaching in organisations. A Maternity Transition Coaching model was designed that is complemented by guidelines for implementing a maternity coaching programme that can be utilised by human resources personnel, senior management and coaches who are exposed to the adverse consequences of senior women leaving the organisations because of the challenges they face during maternity transition.

Keywords: coaching; maternity coaching; maternity transition; working mothers; professional women; retention.

\section{Introduction}

The retention of valuable skills of women at work is critical - organisations cannot afford to lose skills as people are their principal assets. The current world of work is synonymous with ambiguity, change and uncertainty as a result of, among others, socio-economic and political instability and disruption (Bennett, 2017; Smith \& Campbell, 2010). Organisations are challenged to sustain their profitability and grow their success under these difficult conditions. The sustainability of organisations requires a future-proof mindset when it comes to doing business, and managing their employees in particular. These circumstances have brought new challenges for human resource management (Ye, Wang, Wendt, Wu, \& Euwma, 2010). Although the number of women in senior professional positions has improved in recent years, the literature indicates that the percentage of women in senior roles in organisations across the globe is still smaller compared to the number of male leaders (Skinner, 2014).

A positive relationship between the percentage of senior women in organisations and the organisation's financial performance has been suggested by studies conducted in Europe and the United States (US) (Desvaux, Devillard-Hoellinger, \& Meaney, 2008). Furthermore, the positive effects of diversity in organisational demographics include increased knowledge and perspectives (Smith, Morgan, King, Hebl, \& Peddie, 2012). Thus, employing and retaining women employees 
increases not only the much-needed female talent pool but also gender diversity. A question that remains is what suitable supporting mechanisms are needed to retain senior women at critical stages during their working life such as maternity transition.

Although the number of women returning to work after having children is on the increase, studies show that there is still a high proportion of women who choose or consider to 'opt-out' from the workplace after becoming mothers (Bohrer et al., 2020; Sparrow, 2008; Still, 2006). Their reasons for leaving are complex and influenced by several factors such as familial pull and organisational push that they experience at different times in their career (Paustian-Underdahl et al., 2019; Zimmerman \& Clark, 2016). The transition to motherhood can be described as a critical turning point in a working woman's life - a profoundly transformative experience (Smith, 1999). This experience is characterised by changes in identity and a changed psychological contract with the employer (Millward, 2006). The woman's identity now includes the identity of both a mother and a working mother.

Given the paucity of professional women who are in senior roles in organisations, the retention of their skills in the workplace is paramount. It is for these reasons that this research responds to the call put forward by Noon and Van Nieuwerburgh (2020) to develop enabling environments in organisations and explore specifically how maternity coaching can provide support for the transition of professional women into working mothers.

\section{Research purpose}

The existing literature and empirical research on maternity coaching are limited, and where it does exist, it is based on overseas contexts, predominantly the United Kingdom (UK), Australia and the United States. The Australian study by Skinner (2014) indicated a positive experience where maternity coaching was provided. The maternity transition period is a time when feelings of vulnerability and low selfconfidence are typically experienced; and maternity coaching sessions can provide a secure space and a place of containment for women in maternity transition (Florent-Treacy, 2009). A support process through coaching, for example, is needed to create a space for women that allows for 'on and off ramps' (Hewlett, 2002, p.168) in this particular stage of their lives.

The role of maternity coaching in supporting and ultimately retaining professional women in South African organisations has not been fully explored. The purpose of this exploratory research is to understand the role of maternity coaching in organisations where it is offered. Furthermore, maternity coaching is an under-researched area in the overall study discipline of coaching. This article pioneers the exploration of this niche form of coaching in South African organisations by conceptualising a maternity coaching model with practical guidelines that emerged from the themes in the study and could be used to implement maternity coaching at work.
Whereas this study utilised the characteristics experienced by women working in South African-based organisations, the guidelines and recommendations for successful maternity coaching can be applied in any organisation that experiences challenges regarding the retention of professional women during and after maternity.

\section{Literature review}

Maternity coaching, an emerging supporting intervention mechanism, has been used for women in maternity transition in organisations in the UK since 2005 (Sparrow, 2008). In her study on the influence of maternity coaching on women's re-engagement with their careers postmaternity leave, Filsinger (2012) asserts that maternity coaching is a new genre of coaching and its long-term impact on women and organisations is not yet fully understood. It is furthermore unclear how widespread maternity coaching is offered in South African organisations, and there is a lack of empirical research on coaching aimed at supporting professional women, for example those in middle level to senior roles, who have experienced the transition from maternity leave into motherhood. The next section provides an overview of the theories and empirical findings which informed this study.

\section{Professional women in organisations}

This study focuses on 'professional women', ${ }^{1}$ a term that can be understood as women in middle- to senior-level management positions or leadership roles. The latest Thornton Grant report stated that Africa as a region was well ahead of the global average of senior roles in organisations being held by women in 2021 (Africa: 39\%; globally: 31\%). Globally, an increase in senior positions held by women by 2\% was noted between 2019 and 2021 (Thornton, 2021), an encouraging progress. Yet, for South African Organisations, a report from the South African Women in Leadership Census conducted by the Businesswomen's Association of South Africa (BWASA) in 2017 paints a picture of an insufficient representation of women in corporations listed on the Johannesburg Stock Exchange (JSE). These reports indicate that organisations have made mixed progress in this respect regardless of the possible commercial benefits, explicitly financial performance of an organisation which could be achieved through gender diversity (Hunt, Layton, \& Prince, 2015; Skinner, 2014; Stout-Rostron, 2013; Vitzthum, 2017).

Reasons for the challenge to retain professional women are 'multifaceted' (Vitzthum, 2017), ranging from different career phases and life stages, to barriers to women's leadership careers, such as a harsh organisational culture and prevailing male leadership norms, and opting-out because of the complexity of the various roles a woman has to fulfil, specifically, when she transitions from a professional woman to a working mother. During this time, women reconsider their career aspirations or opt-out completely.

1.In this study, the term 'professional women' is interchangeably used with the terms 'women' and 'working women'. 


\section{Women's careers}

It has been recognised that the evolvement of women's careers is different to those of men (Liff \& Ward, 2001). According to Clarke (2011), 'roles, relationships and responsibilities such as spouses' careers, child-bearing, childrearing, and the care of elderly family members' (p. 499) tend to shape a woman's career. Although men are also faced with these constraints, women have typically adopted the role of the primary caregiver, so their careers are most likely to be disrupted during the childbearing ages with a further consequence of family responsibilities (Ackah \& Heaton, 2004, cited by Clarke, 2011). Recognising that women's careers develop over time differently to those of men $\left(\mathrm{O}^{\prime} \mathrm{Neil}\right.$ \& Bilimoria, 2005), it is necessary to consider and understand what confronts women as they navigate the 'professional labyrinth' (Eagly \& Carli, 2007). Metaphorically speaking, the labyrinth signifies a journey punctuated with complexity and challenges women face during their careers (Skinner, 2014). Phrases such as 'barriers', 'gender stereotypes', 'conscious and unconscious bias', 'glass ceiling', 'leadership norms', 'societal gender norms' and 'workplace culture' characterise women's experiences in the workplace (Eagly \& Carli, 2007; Skinner, 2014). It is argued that if these experiences are understood by the organisation, effective support can be given to 'improve the situation' (Eagly \& Carli, 2007, p. 64), aiding the success of women in senior roles in general (Ely \& Rhode, 2010, cited in Skinner, 2014) and when professional women transition through maternity.

\section{Maternity transition}

The journey to motherhood is a transformative experience. For women who undergo this experience, it is a significant period of intense physical, psychological and social changes (Boz, Özçetin, \& Teskereci, 2018; Brown \& Hodges, 2016). Therefore, the period of leaving the organisation to go on maternity leave and then transitioning back to the workplace can be challenging. This period includes a re-prioritisation of values and life goals, issues of self-confidence and role identity, trying to manage multiple roles and the ensuing potential role conflict (Morris, 2008) as well as the questioning of the meaning of work (Bussell, 2008; Filsinger, 2012; Spence, Armour, Driessen, Lea, \& North, 2016). It is a time characterised by sense-making, reflection and weighing up options with shifting perspectives towards their career, the organisation they work for and towards the world (Bussell, 2008; Mainiero \& Sullivan, 2005). Changes in self-identity and changed psychological contracts are key components of how women try to make sense of their transition into motherhood, as reported in the study by Millward (2006).

For the purposes of this study, the transition experience of professional women is categorised into three phases: the 'during pregnancy' phase, the 'during maternity leave' phase and the 'return-to-work post-maternity leave' phase. During the third (last) phase, when the women as mothers return to the workplace, they encounter multiple organisational and family roles (being a worker, a mother and a working mother). The switching of these roles can be defined as either physical or psychological shifts between roles and domains (Ashforth, Kreiner, \& Fugate, 2000). The maternity transition and the various proverbial 'hats' that a woman wears in this process can result in role and identity conflict and confusion (Grady \& McCarthy, 2008), as she tries to manage and bring order to her environment. The complexity and strain of these various roles are experienced when the woman finds it difficult to meet the demands and expectations of these roles (Voydanoff, 2002), or when she is concerned about her ability to perform optimally in both her roles in respect of work and family commitments (Matthews, Winkel, \& Wayne, 2014). Transition theory with a focus on role and career transition in the workplace aids in understanding how individuals experience times of transition in their lives (Anderson, Goodman, \& Schlossberg, 2012; Bridges, 1980; Schlossberg, 1981), which is useful for this study on maternity transition. Bridges (1980) and Schlossberg (1981) describe the process of transition occurring in stages - a process of moving through the transition, letting go of the old and engaging with the new situation. As part of letting go, the professional woman may have to let go of the way things used to be, for example, working long hours or rethinking business travel when the baby arrives (Laney, Hall, Anderson, \& Willingham, 2015). In his model, Bridges (1980) introduced the idea of transition versus change, with transition being more complex than change. He argues that change is external and situational, whereas transition is a psychological process that people go through during which they come to terms with all the aspects of change. Schlossberg (1981) further considers the element of self-perception and its role in the transition - the way an individual sees a situation and herself within that specific situation, a topic which could be explored during maternity coaching to help professional women making sense of their new situation.

\section{Maternity coaching}

One of the objectives of maternity coaching is to re-integrate professional women with their careers once they return from maternity leave to the organisational context. Maternity coaching thus offers an opportune time to assist women to map their career decisions following their maternity transition, such as opting-out or opting in-between (Cabrera, 2007). Maternity coaching was found to influence women's re-engagement with their career development by preparing them at an emotional level, at a practical level and at a reflective level regarding their careers (Filsinger, 2012). Research by Bussell (2008) found that the maternity transition period does not stop when a woman returns to work postmaternity leave, but rather continues until her child becomes independent.

The lack of empirical data on the fundamental aspects of maternity coaching, such as the coaching skills of a maternity coach, the sequence of coaching sessions and specific guidelines for organisations to implement maternity coaching, has been responded to with this study. 


\section{Method}

\section{Research approach}

This qualitative exploratory study followed an inductive approach with the primary goal of 'describing and understanding rather than explaining human behaviour' (Babbie \& Mouton, 2014, p. 270). Qualitative research is rooted in a constructivist philosophical position and is concerned with how a complex social phenomena are experienced, interpreted and understood (Bloomberg \& Volpe, 2008). This feature of qualitative research resonates with the study.

\section{Research design}

A descriptive case study design, applied as an in-depth investigation, was conducted of a single case unit, namely maternity coaching (Delport, Fouché, \& Schurink, 2011). To gain a deeper understanding of the role of maternity coaching, a cross-sectional and multi-perspective research design was selected. Triangulation was used firstly to check and establish validity in studies by analysing a research question from multiple perspectives (Guion, Diehl, \& McDonald, 2010), secondly to build the strength of inquiry (Henning, Van Rensburg, \& Smit, 2004) and thirdly triangulation is rich, robust, comprehensive and well developed (Creswell, 2009). A purposive sampling process was adopted to identify and select the research participants from four professional groups. With this selection process, it was possible to gather valuable information about maternity transition and maternity coaching (Bloomberg \& Volpe, 2008; Merriam, 1998). The demography of the four participant groups (consisting of 13 participants in total) is provided in Table 1.

A semi-structured interview was used to collect data because it has the potential to elicit participants' 'subjective reality' (Henning et al., 2004, p. 52) - what they feel, do, and think about the topic and 'how they make meaning of their own lives, experiences, and cognitive processes' (Yin, 2011, p. 135).

TABLE 1: Rational and inclusion criteria for the four participant groups from different corporate organisations.

\begin{tabular}{|c|c|c|c|}
\hline Participant group & Number & $\begin{array}{l}\text { Demographic } \\
\text { information }\end{array}$ & Research objective \\
\hline $\begin{array}{l}\text { 1. Professional women in } \\
\text { middle to senior } \\
\text { positions who had } \\
\text { received maternity } \\
\text { coaching in the } \\
\text { preceding } 24 \text { months }\end{array}$ & 3 & Age: $30-40$ years & $\begin{array}{l}\text { To explore the experiences } \\
\text { of professional women who } \\
\text { had received coaching } \\
\text { during their transition into } \\
\text { maternity leave in an } \\
\text { organisational context. }\end{array}$ \\
\hline $\begin{array}{l}\text { 2. Professional women in } \\
\text { middle to senior } \\
\text { positions who had not } \\
\text { received maternity } \\
\text { coaching and had } \\
\text { returned from } \\
\text { maternity leave in the } \\
\text { preceding } 24 \text { months. }\end{array}$ & 3 & Age: $30-40$ years & $\begin{array}{l}\text { To explore the experiences } \\
\text { of professional women who } \\
\text { returned to the } \\
\text { organisations after being on } \\
\text { maternity leave, but who } \\
\text { had not received any } \\
\text { maternity coaching. }\end{array}$ \\
\hline $\begin{array}{l}\text { 3. Professional coaches } \\
\text { who had coached } \\
\text { women in maternity } \\
\text { transition in the } \\
\text { preceding } 24 \text { months }\end{array}$ & 4 & $\begin{array}{l}\text { Tenure: an average } \\
\text { of } 10 \text { years }\end{array}$ & $\begin{array}{l}\text { To explore the experiences } \\
\text { of coaches who had } \\
\text { coached professional } \\
\text { women during their } \\
\text { maternity transition into } \\
\text { motherhood. }\end{array}$ \\
\hline $\begin{array}{l}\text { 4. Organisational } \\
\text { stakeholders who had } \\
\text { implemented } \\
\text { maternity coaching }\end{array}$ & 3 & $\begin{array}{l}\text { Occupation: two } \\
\text { human resource } \\
\text { (HR) practitioners, } \\
\text { one line manager }\end{array}$ & $\begin{array}{l}\text { To explore the experience } \\
\text { of organisational } \\
\text { stakeholders who had } \\
\text { implemented maternity } \\
\text { coaching. }\end{array}$ \\
\hline
\end{tabular}

The interviews centred on the following topics:

Group 1: Professional women who had received maternity coaching:

- Individual maternity transition experience.

- Maternity coaching experience.

Group 2: Professional women who had not received maternity coaching:

- Individual maternity transition experience.

Group 3: Professional coaches:

- Challenges that professional women face during maternity transition.

- Approach to and impact of the maternity coaching programme.

Group 4: Organisational stakeholders:

- Purpose and contribution of the maternity coaching programme.

Participants who had a maternity coaching experience were prompted on their views about the strengths and weaknesses of the maternity coaching programme and on suggestions how to improve it.

\section{Data analysis}

The data analytical cycle recommended by Yin (2011) was followed in the present study and involved five steps: compiling and sorting filed notes into an electronic database; disassembling the data by assigning codes to the data; reassembling the data into themes and categories; interpreting the re-assembled data; and drawing conclusions from the study relating to the interpretation of the data. The analysis was an ongoing, emerging and non-linear process (Henning et al., 2004), which allowed for an iterative relationship with the raw data, and enabled cycling through the five steps more than once. The findings were interpreted in the context of literature presented in the literature section and with additional new literature responding to the themes that emerged.

To give emphasis to the personal stories of the women who had experienced maternity transition with or without coaching, the researchers were compelled to use a pseudonym female name for each woman participant. Code names were applied to the coaches and stakeholders (C1-C4 for the coaches and S1-S3 for the stakeholders). Table 2 shows the sample groups and the names used during the analysis.

TABLE 2: Sample groups with pseudonyms and code names.

\begin{tabular}{|c|c|c|}
\hline Sample groups 1 to 4 & Participants & Pseudonym/code name \\
\hline $\begin{array}{l}\text { Professional women who had } \\
\text { received coaching }\end{array}$ & Participants $1-3$ & Jen; Sarah; Michelle \\
\hline $\begin{array}{l}\text { Professional women who had } \\
\text { not received coaching }\end{array}$ & Participants 1-3 & Bianca; Rani; Emma \\
\hline Coaches & Participants $1-4$ & $\mathrm{C} 1-\mathrm{C} 4$ \\
\hline $\begin{array}{l}\text { Organisational stakeholders } \\
\text { (line manager and human } \\
\text { resource professionals) }\end{array}$ & Participants $1-3$ & S1-S3 \\
\hline
\end{tabular}




\section{Ethical considerations}

The ethical considerations were underpinned by the ethical code of Stellenbosch University, which included the informed consent given by participants (ethical clearance number USB2018-6536).

Appropriate measures were taken to ensure harm was minimalised to participants by following principles of participation, consent, anonymity and confidentiality (Bloomberg \& Volpe, 2008). Information about the purpose and process of the study was shared with the participants in a letter beforehand so that a voluntary and informed choice to participate in the study could be made (Leedy \& Ormrod, 2013).

\section{Results}

The findings from the thematic analysis have been synthesised and refer to the following three aspects: the 'why', the 'how' and the 'what' of maternity coaching. Next follows a brief discussion of the findings in this study.

\section{Findings and discussion}

The findings of this study point to maternity transition of professional women in organisations as being complex, challenging and transformative in nature. Furthermore, maternity coaching was found to play a positive role in assisting the professional women and the organisations to progress through the maternity transition journey. The findings emphasise why maternity coaching is needed as a mechanism of support in maternity transition. They also indicate how maternity coaching should be implemented and what should typically be covered in the maternity coaching conversations. A maternity coaching framework was developed from the interpretation of the findings and related existing theories (Creswell, 2009). This framework provides the guidelines for the different participant groups: professional women (two groups), professional coaches, and human resources practitioners and line managers.

\section{The 'why' of maternity coaching}

In making sense of the purpose of maternity coaching, it was first necessary to explore the maternity transition experience of professional women, for example those who did and those who did not receive maternity coaching, and secondly, why it was offered by companies represented in this study and by the coaches who had been contracted for their coaching services. These experiences, in turn, were divided into two categories: the maternity transition experience in the context of the work environment and the experiences during the three maternity transition phases.

\section{The maternity transition experience in the context of the work environment}

The findings from the experiences of women in the context of the work environment provide insights on the impact that organisational culture and organisational support had on the maternity transition experience. Although organisational support is inextricably linked to organisational culture, it is presented separately here because of its prominence in the experiences of the working mothers, the organisational stakeholders and the coaches.

Time and hours of work can be seen as a manifestation of organisational culture and, as a result, time and hours have 'multiple cultural meanings in organisations', as suggested by Cahusac and Kanji (2014, p. 59). For example, working longer hours can be associated with male practices causing conflicting demands for women between career and family (Watts, 2009; Williams, 2001). In the present study, all working mother participants expressed the difficulty in keeping up with time-related expectations after returning from maternity leave, as illustrated by Emma:

'[Whereas] I used to work until six in the evenings, I [now] had to start leaving at four, because I had to relieve my nanny. So that was a massive thing for me: to get up and say I have to leave now, or to decline a meeting when it was at five o'clock in the evening and I really can't be there.' (Emma, Professional woman not received coaching, P3)

The topic of time that emerged in this study not only related to issues such as long hours, but also related to the lack of flexibility and role strain, which point to the need for an organisational culture that recognises and supports the working mother. This need for a supportive organisational culture also correlates with literature on the topic (see Brown, 2010; Cabrera, 2007; Cahusac \& Kanji, 2014; Hewlett \& Luce, 2005; Mainiero \& Sullivan, 2005).

Organisational culture emerged as a prominent theme in both the interviews with the coaches and stakeholders. They offered examples where the organisational culture had influenced the maternity transition, the experiences of working mothers and, to varying degrees, their retention as talent. A stakeholder representative (S3) shared her experience of working mothers' feelings that they had to leave because the organisational culture had not been familyfriendly:

'Women just get punished, I mean that's just the way it is ... I ran a survey to understand career aspirations of women, and working mothers have said it's really difficult to pursue their career, because of the lack of support and openness to flexible work time; working mothers and their many roles ... they kind of see themselves being forced into a position where they [have to] leave (S3).'

The importance of an organisational culture in supporting working mothers and directly influencing the success of their maternity transition was highlighted in this study and in others, notably those by Cabrera (2009a, 2009b), Cahusac and Kanji (2014) and Ludeman (2009).

The male-dominated representation in senior leadership roles was described by the coaches and stakeholders. Coach C4 reflected that: 
'... women ... are saying: there are not a lot of senior women in the workplace ... when I come back to the office ... who is there that looks and feels like me?' (C4)

One of the women participants (Jen) also observed this experience:

'I do think that the (pause) senior leaders in the team who mainly happen to be white males (giggle), they sort of lack a bit of sensitivity to apply to the working mom and [..um] females in general.' (Jen, Professional woman received coaching, P1)

The under-representation of women in leadership and senior roles was highlighted as a concern by the coaches and stakeholders, which, according to them, could translate into a male hegemonic organisational culture. The literature further suggests that the manifestation of male norms could result in a lack of maternal-related support - women feeling isolated and unable to fit in; a lack of family-friendly policies; a challenged work-life balance experienced by women; and an absence of female role models who are working mothers and leaders (Cahusac \& Kanji, 2014; Ludeman, 2009; StoutRostron, 2013; Vitzthum, 2017).

The second theme of organisational support is related to the maternity transition experience. A line manager's role, support and involvement, in particular, were expressed by the women participants as key factors in their maternity transition experience. It was interesting to observe that where maternity coaching was received, the line manager's role and attitude in how close or distant they remained towards the maternity transition journey were critically important to the women participants. This was explained by Sarah when she was asked about her line manager's involvement:

\footnotetext{
'... I also think having a supportive line manager, and being in an organisation that supports you helps ... you can go to as many coaching sessions as you want, if you don't have a supportive line manager then you are going to struggle.' (Sarah, Professional woman received coaching, P2)
}

Sarah's experience highlights the importance of a leader's role in embodying and creating an organisational culture that is family-friendly and supportive of working mothers (Brown, 2010; Bussell, 2008; Cabrera, 2009a, 2009b; Still, 2006; Sullivan \& Mainiero, 2008).

Maternal support structures in organisations could include maternity leave benefits, policy procedure processes, a lactation room and contracting with the organisation prior to maternity leave. Women participants said that they had to fend for themselves in finding out about maternal support and, in some cases, were still unsure about the organisation's stance on the support. This lack of coordinated maternal support and the need for more open communication were discussed alongside descriptions of the organisational culture. The organisational culture was not experienced as conducive to have certain conversations by Michelle and it exposed one's vulnerability, as she stated:

'It's like some kind of discussion that we don't talk about, like I feel maternity leave is a very ... it's a very difficult conversation to have. You kind of tell them you are pregnant and then deny it for how many months, but then you physically get bigger, then you go on maternity leave and then you quickly get re-introduced again. They pretend that nothing happened, you know.' (Michelle, Professional woman received coaching, P3)

The lack of support for the women participants who were in their transition process into motherhood dominated the interviews which revealed the following:

- a lack of acknowledgement of the multiple roles women have;

- a lack of psychological safety;

- a lack of support from line managers and female leaders in the organisation, specifically those who do not have children;

- a lack of conversations in the workplace about maternity transition and motherhood in general; and

- a lack of support by the entire organisational system.

Overall, it was evident that extensive support throughout the organisation was critical to ensure that the working mother experiences a positive, integrated and smooth journey back into the workplace as she re-engages with her career.

\section{The experiences during the three maternity transition phases}

The maternity transition experience is discussed in the context of the three phases of maternity transition. During the prematernity leave phase, women are typically work-focused. As a result, women participants experienced their pregnancy transition as stressful, fearful and overwhelming. Some participants even considered concealing their pregnancy for as long as possible because of the fear (perceived or real) of the impact it might have on their careers and how their pregnancy would be received in the organisation. Michelle admitted her fear and feelings of guilt:

' $[I]$ was still terrified to tell them that I was pregnant. I felt guilty and I felt like I was going to put the company under a lot of strain.' (Michelle, Professional woman received coaching, P3)

A study by Haynes (2008) correspondingly confirmed that women were reluctant to disclose their pregnancy to their organisation in fear of jeopardising their careers.

The pressure to perform exactly at the same level as before pregnancy was a result of self-pressure and/or perceived organisational expectations that was also emphasised in the work of Murphy and Zorn (1996) and Millward (2006). The following two excerpts illustrate both the fear and ambition to fulfil the organisational performance expectations:

'The anxiety that hit me after I fell pregnant was: Will I still be able to put in that same effort that I've put in before - and that was like working until two or three in the morning - now that I'm pregnant?' (Rani, Professional woman not received coaching, P2)

Jen referred to her pregnancy as a 'side show' in describing its possible impact on her performance: 'Life is already so busy, you don't really stop too much to think about this little baby growing inside you'. 
Thus, to meet performance expectations and to add value were common and prominent challenges facing the women participants.

The pre-maternity phase is further characterised by changes in the physical body and the related effects such as fatigue, tiredness and physically growing bigger, therefore losing control over one's body (Millward, 2006; Murphy \& Zorn, 1996). These changes and effects were also highlighted to varying degrees by the women participants in the present study. As the pregnancy progressed, the women mentioned that they had planned and prepared for the handover before going on maternity leave. Handing over their work to a colleague or distributing it among the team, however, evoked further feelings of guilt among some of the participants. Michelle described this as a 'double bind' of guilt-feeling guilty for handing over work to her colleagues and taking maternity leave. The importance of contracting with the line manager prior to going on leave on aspects such as the duration of maternity leave, expectations of engagement with the workplace during maternity leave and the handover to others were emphasised as important elements to manage this transition successfully, especially by those women who had received maternity coaching.

A key aspect that emerged from the during maternity leave phase was the women's adjustment in their transition from a 'working woman' to a 'mother role' identity. This transition requires a shift in identity, making sense of the new role as a mother, and adjusting and setting boundaries (Millward, 2006). Overall, women participants said that they had enjoyed their motherhood and the time spent with their baby to varying degrees. However, there were feelings of insecurity and uncertainty about their role back at work, especially during the first few weeks of maternity leave. Although they felt that it was important to be fully on maternity leave without the burden of worrying about work, it was still important to all of them to have made some form of contact with their organisation during this time. The contact made by the line manager in particular was highlighted as valuable as confirmed by two participants:

'I don't know, you expect the odd message to say: "Hope you're well, how's it going?," but at the same time I'm like either, have they forgotten about me or they are just being pretty respectful and leaving me to be, and not think about work and them? (Bianca).' (Bianca, Professional woman not received coaching, P1)

When Rani received a congratulations call from her line manager she felt that she was being acknowledged: 'Congratulations, you had a baby, so awesome, we're thinking of you'.

Another significant point in this phase lies in the preparation to return to work. It is a juncture that Lee (1984) typified by feeling emotionally torn between leaving the child behind and returning to work, as Sarah noted: 'It was very-very-very hard for me [to] think about leaving my baby'. Feelings of doubt regarding whether she would still be needed by the organisation and a lack of self-confidence in her ability to return to work and manage motherhood after the absence emerged in the interviews. This same sentiment was also illustrated by Jen: '... well, it's not really a big thing for everyone else that's kind of carried on without you, for the last few months'. In their preparation to return to work, the women participants raised the consideration of support, specifically arranging childcare to ensure a smooth transition back into the workplace.

The study revealed that working mothers found the returnto-work post-maternity leave phase to be difficult, especially the re-integration into the organisation. It was described as an emotional journey with physical demands, which Rani testified: 'I cried my heart out ... (crying) ... because I wanted to be there for my son, that was the biggest thing for me'. The physical demands on the women participants who had chosen to continue breastfeeding were pressuring them to find time to express milk in the workplace. Michelle raised the concern that the absence of a dedicated space, such as a 'lactation room', and excusing oneself to express milk, was challenging and 'embarrassing'. The overall theme in the early months upon return was associated with anxiety about the change in self, perceived change in the organisation and finding one's way in the working mother journey. Finally, the notion of career considerations (Mainiero \& Sullivan, 2005), career decisions and working mothers' dependency on their individual and family circumstances were highlighted by the women participants, leading to pragmatic conclusions, such as the one made by Jen:

'For now, I think I've made peace with the fact that [...] I don't want a massive, another sort of massive leap in my career.' (Jen, Professional woman received coaching, P1)

Most of the coaches agreed that the women's guilt feelings related to their perceived ability to fulfil performance expectations. This pressure, which they had placed on themselves to perform in exactly the same way prior to their pregnancy, was listed as a major contributor to the stress and anxiety the women participants typically experienced. Millward (2006) found similar themes associated with changed psychological contracts, which relate to the fulfilment of mutual performance expectations between the employer and the employee.

Feedback on the maternity coaching experience was found to underline the positive role it played in supporting women who had returned to the organisation after their maternity leave, for example articulated by Michelle:

'The guilt and all of that ... those are the type of things that you work on during maternity coaching, [it] helps you to see the long-term benefits, um [pause]... it is something that helps you keep perspective ... and helps women stay in the workplace.' (Michelle, Professional woman received coaching, P3)

An overview of the synthesised themes derived from the interviews in responding to the 'why' of maternity coaching is provided in Table 3. 
TABLE 3: Understanding the maternity transition experience: the 'why' of maternity coaching.

\begin{tabular}{|c|c|c|}
\hline Experience & Working mothers & Coaches and stakeholders \\
\hline \multirow{3}{*}{$\begin{array}{l}\text { 1. Transition } \\
\text { experiences in } \\
\text { the context of } \\
\text { the work } \\
\text { environment }\end{array}$} & Participant groups 1 and 2 & Participant groups 3 and 4 \\
\hline & $\begin{array}{l}\text { Organisational culture } \\
\text { - Complex, highly pressured, } \\
\text { high performance } \\
\text { - Lack of balanced } \\
\text { gender representation in } \\
\text { leadership }\end{array}$ & $\begin{array}{l}\text { Organisational culture } \\
\text { - Harsh organisational culture; } \\
\text { dominant male leadership } \\
\text { norms } \\
\text { - Lack of female role models in } \\
\text { leadership } \\
\text { - Perceptions, assumptions and } \\
\text { judgements about working } \\
\text { mothers }\end{array}$ \\
\hline & $\begin{array}{l}\text { Organisational support } \\
\text { - Importance of line } \\
\text { manager's support } \\
\text { - Availability or lack of } \\
\text { maternal support }\end{array}$ & $\begin{array}{l}\text { Organisational support } \\
\text { - Lack of acknowledgement of } \\
\text { women's multiple roles } \\
\text { - Lack of support from line } \\
\text { manager and female leaders } \\
\text { - Lack of conversations about } \\
\text { maternity transitions }\end{array}$ \\
\hline \multirow{9}{*}{$\begin{array}{l}\text { 2. Experiences } \\
\text { during the } \\
\text { three maternity } \\
\text { transition } \\
\text { phases: } \\
\text { pre-maternity } \\
\text { phase, during } \\
\text { maternity leave } \\
\text { phase and } \\
\text { return-to-work } \\
\text { post-maternity } \\
\text { leave phase }\end{array}$} & Pre-maternity phase & Pre-maternity phase \\
\hline & $\begin{array}{l}\text { Anxiety and fear } \\
\text { Pregnancy impact } \\
\text { Concealing pregnancy } \\
\text { Changes in physical body } \\
\text { Performance expectations }\end{array}$ & $\begin{array}{l}\text { Disclosure of pregnancy } \\
\text { Change and control }\end{array}$ \\
\hline & $\begin{array}{l}\text { Planning for maternity leave } \\
\text { Handing over work } \\
\text { Contracting with line manager }\end{array}$ & $\begin{array}{l}\text { Preparing for maternity leave } \\
\text { Contracting with the } \\
\text { organisation }\end{array}$ \\
\hline & During maternity leave phase & During maternity leave phase \\
\hline & $\begin{array}{l}\text { Adjustment } \\
\text { - Identity from working } \\
\text { woman to working mother } \\
\text { - Multiple roles } \\
\text { - Challenged by boundaries }\end{array}$ & $\begin{array}{l}\text { Adjustment } \\
\text { - Changes to physical body and } \\
\text { demands } \\
\text { - Role } \\
\text { - Identity } \\
\text { - Anxiety }\end{array}$ \\
\hline & $\begin{array}{l}\text { Planning to return to work } \\
\text { - Childcare }\end{array}$ & $\begin{array}{l}\text { Readiness to return to work } \\
\text { - Practical readiness } \\
\text { - Psychological readiness }\end{array}$ \\
\hline & $\begin{array}{l}\text { Return-to-work post- } \\
\text { maternity leave }\end{array}$ & $\begin{array}{l}\text { Return-to-work post-maternity } \\
\text { leave }\end{array}$ \\
\hline & $\begin{array}{l}\text { Emotional journey } \\
\text { Lack of self-confidence } \\
\text { Physical demands } \\
\text { Line manager's role }\end{array}$ & $\begin{array}{l}\text { Adjustment } \\
\text { Support structures } \\
\text { Work-life balance }\end{array}$ \\
\hline & $\begin{array}{l}\text { Identity and multiple roles } \\
\text { Career planning }\end{array}$ & $\begin{array}{l}\text { Identity } \\
\text { Career planning }\end{array}$ \\
\hline
\end{tabular}

These findings illustrate the complexity and transformative nature of the maternity transition experience, which is the basis why maternity coaching is needed and upon which the coaching intervention can be designed.

\section{The 'how' of maternity coaching}

The maternity coaching process was not experienced the same by the three women participants who had received maternity coaching, or by the coaches who and the organisation that offered maternity coaching. The study, however, revealed that the structure of the maternity coaching programme consisted typically of three phases, namely coaching during the pregnancy phase; coaching whilst on maternity leave; and coaching upon return to the workplace. These phases align with Beacom's Maternity Leave Transition Coaching Model (Beacom, 2013).

The number of coaching sessions ranged from 4 to 10 with the nature of the conversations being both practical and psychological to assist the women to move through the transition. In some instances, depending on the organisation, line manager consultations were included as part of the maternity coaching programme, which entailed the coach meeting with the line manager to help them prepare and support the women during their maternity transition. Sessions were held during the maternity leave period (usually two sessions) and upon return to work. The postmaternity sessions were typically scheduled to start around 6 weeks after the women returned to work and then again in 6- to 8-month intervals. The overall number of coaching sessions and timing, especially at the post-maternity leave phase, depended on what had been contracted with the organisation as part of the maternity coaching programme. Aspects such as costs and seniority or job levels would influence the structure of the maternity coaching programme.

According to Sarah, the maternity coaching journey was an 'immensely positive' experience for those women who had received it. It was described by women as a space where one was challenged but where they felt safe and secure; where they could be vulnerable and have time to think. Michelle reflected on the benefit of being able to talk about her fears:

'[T] he coach shared her own experiences and that of other women ... this is what many women do ... it was good to have a sounding board, and how I was feeling was kind of normalised.' (Michelle, Professional woman received coaching, P3)

The coaching journey as a safe 'container' for the women to be able to feel vulnerable and have a space to think was also emphasised by Stout-Rostron (2013).

In describing their experience with the maternity coach, all three women participants reported that they had derived much benefit from it. They experienced relevance and a connection to the maternity coach because of the coach's own maternity transition experience in an organisational context. The maternity coach was seen as a credible role model, mentioned by Sarah:

'[I] definitely think the fact that my coach was someone who was experienced and went through the same thing as well [...] I think in this context it creates credibility.' (Sarah, Professional woman received coaching, $\mathrm{P} 2$ )

These findings support Liston-Smith's (2011) suggestion that a maternity coach who has also been through maternity transition is able to offer empathy and to be a mentor to the women.

\section{The 'what' of maternity coaching}

The 'what' of maternity coaching refers to the content covered in the maternity coaching sessions. As confirmed by the coaches, the overall aim of the coaching was to support women to effectively transfer from pregnancy into maternity leave and to retain them in the workplace upon their return. Preparing and assisting the women in a safe space at an emotional and practical level were therefore necessary in the coaching sessions. As a result, the coaching sessions were structured to make provision for both practical and emotional conversations, for example, on their work and 
career. For example, during the pre-maternity phase sessions the women were encouraged to compile a '30-day plan' as they prepared to handover their work before going on maternity leave. These conversations entailed role playing in, for example negotiating flexible work hours, maternity leave and other maternity benefits. Overall, the nature of the coaching conversations during the pre-maternity phase focused on preparing the individual woman to go on maternity leave and to help her to develop courage to have difficult conversations with line managers. Michelle reflected that:

' $[A]$ maternity coach does help ... it gives you that boost to go and have that difficult conversation, and to realise that you are actually important enough to have that conversation.' (Michelle, Professional woman received coaching, P3)

During the maternity leave, the coaching conversations prepared the women to re-enter the organisation postmaternity leave. Practical aspects, such as childcare, household support and the nature of their partners' involvement, were discussed during these sessions. On a deeper level, it was a time when women had to work through a mixture of emotions - feelings of guilt in leaving the child to go to work; fear of re-entering the workplace; low levels of self-confidence in their abilities; uncertainty in balancing motherhood and work; and some women questioning whether to return to work at all. Sarah described her feelings during this time and what she had shared during the coaching session:
'I was enjoying being a mom and being at home ... to leave my baby behind, the guilt was quite a lot for me to deal with. And just the fear of the unknown ... there is a whole other part of your life that never existed before that you are responsible for. Things would have probably changed at work. So it was scary going back.' (Sarah, Professional woman received coaching, P2)

From the conversations with coaches, it emerged that the sessions for the post-maternity leave phase centred on reintegration into the workplace and supporting the working woman who had now become a working mother. The topic of role re-construction was mentioned by Michelle: 'especially with a first child ... you are like, I think there is a whole other role that you have now, you are now a mother'. Themes such as the recurring guilt about working and leaving the child in someone else's care, a work-life balance, family responsibilities, role conflict, and often, much later on the coaching journey, re-assessing one's career aspirations and possibly conversations about another child were discussed. The coaches commented that the maternity coaching programme was tailor-made to every organisation's needs, although the structure and content generally covered the aspects as mentioned in these findings.

These findings contribute towards an in-depth understanding of the complexity of maternity transition at both a practical and psychological level, and broadening the knowledge of

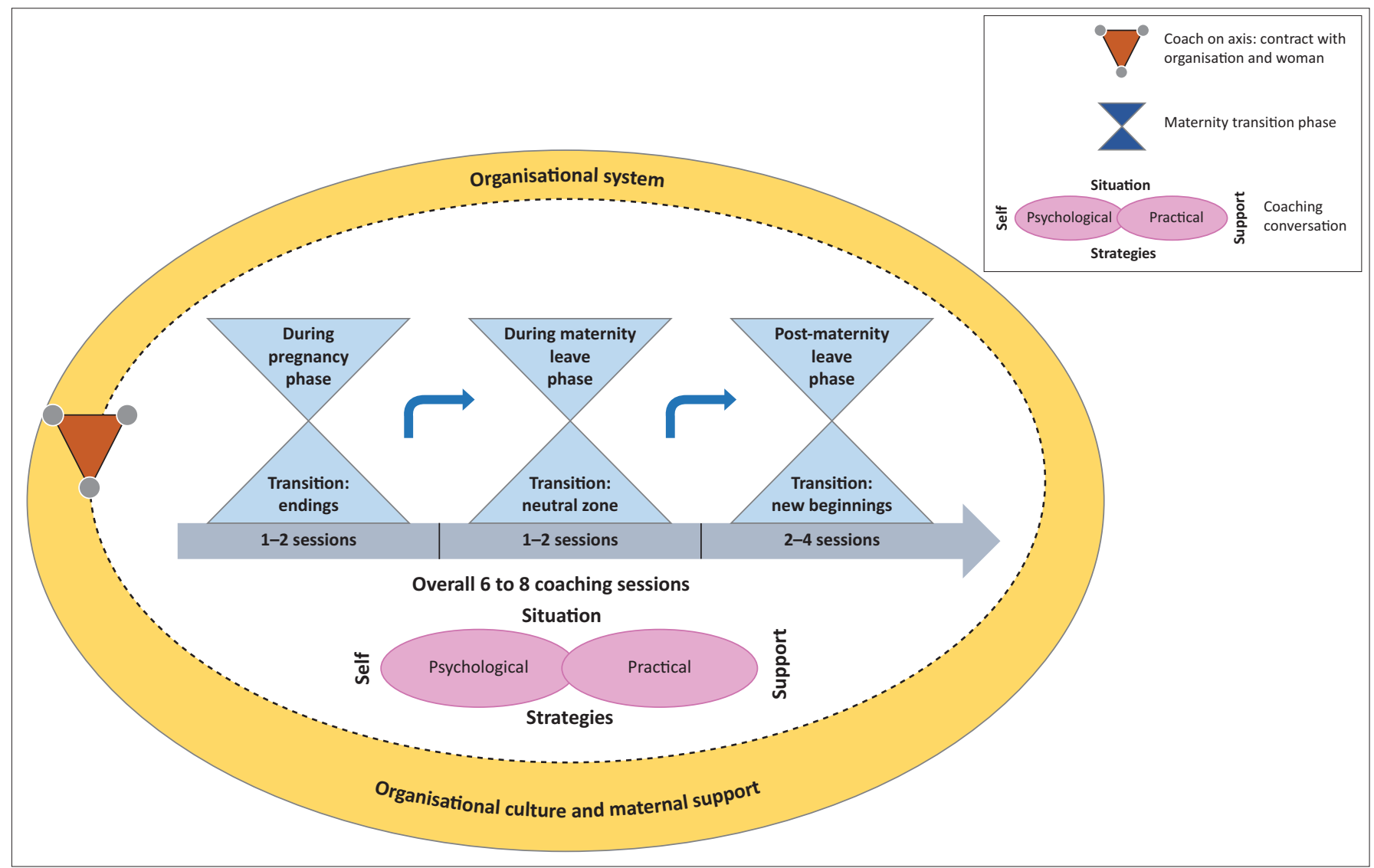

FIGURE 1: Maternity Transition Coaching Model. 
the extensive support required to assist professional women as they become working mothers.

\section{Practical implications: Maternity Transition Coaching Model and guidelines}

The findings have practical implications for organisations on why maternity coaching is needed as a mechanism of support, how it can be implemented and what should be focussed on in the intervention. These three aspects provided the input for the Maternity Transition Coaching Model $^{2}$ and the practical guidelines for the different groups.

\section{The Maternity Transition Coaching Model}

The Maternity Transition Coaching Model can be utilised by organisations to plan and implement the coaching. The maternity coaching, as depicted in Figure 1, is positioned within an organisational system context, illustrated in the form of the outer circle, and the success of the maternity coaching programme is influenced by a supportive organisational culture and maternal support practices within the organisation. The three phases of maternity transition are shown in the centre of the model, with the maternity coaching sessions indicated in each phase. The themes of the coaching sessions are practical and psychologically directed to assist women towards successful maternity transition. These themes are illustrated with conversational themes in the model: situation, strategies, self and support. In the model, the coach moves on the axis of the outer circle and establishes a contract with the organisation and the women.

The Maternity Transition Coaching Model is supported by practical guidelines to ensure that the coaching programme is the intended supportive lever for professional women during maternity transition with the aim to retain middle to senior female leaders in organisations.

\section{Guidelines and practical recommendations for maternity coaching}

The Maternity Transition Coaching Model can be used to plan a maternity coaching programme by considering firstly the guidelines and, secondly, the practical recommendations to the participating groups, namely the professional women, the coaches and the organisational stakeholders.

\section{Guidelines}

The guidelines for implementing a maternity transition coaching programme are shown in Table 4 . An average of six to eight coaching sessions are recommended to complete the coaching programme.

\section{Practical recommendations}

The following recommendations are made to the three participating groups when managing the maternity transition of professional women in organisations.

2.The term 'transition' was included in the Model to emphasise the transitional process through the three phases of pre-, during and post-maternity periods.
TABLE 4: Guidelines for implementing a maternity transition coaching programme

\begin{tabular}{|c|c|}
\hline $\begin{array}{l}\text { Coaching } \\
\text { programme }\end{array}$ & Proposed guidelines \\
\hline \multirow[t]{3}{*}{$\begin{array}{l}\text { Coaching } \\
\text { conversation }\end{array}$} & $\begin{array}{l}\text { During pre-maternity phase the following aspects are important } \\
\text { to consider: } \\
\text { - Coaching sessions } 1 \text { and } 2 \text { can be scheduled any time between } \\
\text { months } 4 \text { to } 8 \text { in the pregnancy phase. } \\
\text { - Key themes prevalent during this phase include: } \\
\text { - Disclosure of pregnancy towards the organisation and } \\
\text { associated fears. } \\
\text { - Change and losing control-physiological changes and } \\
\text { impact of pregnancy on work. } \\
\text { - Planning and preparing for the handover to colleagues and } \\
\text { maternity leave. } \\
\text { - Discussion, negotiation and contracting with line manager } \\
\text { and/or organisation regarding the duration of maternity } \\
\text { leave, benefits and contact during maternity leave. }\end{array}$ \\
\hline & $\begin{array}{l}\text { During maternity leave phase } \\
\text { - Coaching sessions } 3 \text { and } 4 \text { can be scheduled 6-8 weeks before } \\
\text { return date to work. } \\
\text { - Key themes prevalent during this phase include: } \\
\text { - Adjustment and identity: the transition of a working woman } \\
\text { to a working mother identity. } \\
\text { - Readiness to return to work: } \\
\text { - Practical steps and arrangements: childcare; decision about } \\
\text { continuation of breastfeeding; homecare; partner's support. } \\
\text { - Internal readiness: separation from child; decision about } \\
\text { returning to work; anxiety and stress; low self-confidence } \\
\text { about ability to do the work; fears relating to the work } \\
\text { and the organisation; managing workload and balancing } \\
\text { work-home responsibilities. } \\
\text { - Transition period associated with letting go of the old identity } \\
\text { (working woman) and going through a period of uncertainty } \\
\text { towards a new role (working mother). }\end{array}$ \\
\hline & $\begin{array}{l}\text { Return-to-work post-maternity leave phase } \\
\text { - Sessions } 5 \text { to } 8 \text { can be scheduled } 4-8 \text { weeks after being back in } \\
\text { the workplace and then } 6-8 \text { months later. } \\
\text { - Key themes typically prevalent during this phase include: } \\
\text { - Transition back to the workplace: adjustment to new roles } \\
\text { and responsibilities. Coaching provides both practical } \\
\text { support and psychological support. } \\
\text { - Individual woman's degree of readiness to return to work. } \\
\text { - Anxiety and stress: torn between being at work and } \\
\text { leaving child behind (mother's guilt). } \\
\text { - Identity re-construction: working mother. } \\
\text { - Performance: low self-confidence; changing definition of } \\
\text { success; angst- not being fully present at work or at home. } \\
\text { - Balance: multiple roles and responsibilities. } \\
\text { - Career re-engagement and refocusing of goals: career } \\
\text { consideration occurs usually few months post-return. } \\
\text { - Considering having another baby, typically } 12-18 \text { months } \\
\text { post-return. }\end{array}$ \\
\hline $\begin{array}{l}\text { Fundamental } \\
\text { considerations for } \\
\text { the coaching } \\
\text { programme }\end{array}$ & $\begin{array}{l}\text { - Transition theory. } \\
\text { - Identity and identity construction. } \\
\text { - Psychological and practical support and strategies. } \\
\text { - Support from the entire organisational system. }\end{array}$ \\
\hline
\end{tabular}

\section{Professional women}

- Women should recognise that support is needed during this complex transition and accept support by undergoing maternity coaching. They should intentionally and consciously use maternity coaching to help navigate the transition successfully.

- Women should pursue more open communication with the organisation on matters such as inclusion on work projects, career ambition, work travel, contact during maternity leave and other work expectations.

- Women should re-engage and manage their own career objectives upon returning to the workplace by having conversations with line managers about career aspirations, timing of next career steps, managing the workload and career commitments.

\section{Coaches}

- The transition theory and process, together with its associated impact on identity and identity construction during maternity transition, should be highlighted in the development and training of maternity coaches. 
- Coaches should be mindful and aware of the role and impact of the organisational context and culture in supporting women. And, therefore, coaches should engage and give feedback to organisational stakeholders on aspects in the organisational context that could support or that may hinder the maternity transition. This should be done generalised to safeguard the confidentiality of the coaching relationship with the participants.

Organisational stakeholders, such as HR practitioners and line managers:

- Support, in the form of maternity coaching, for example, should be provided to professional women, concentrating on both the physical and psychological challenges of maternity transition. The support could extend to parental and paternity coaching.

- It should be acknowledged that the organisational culture plays a critical role in supporting women in their maternity transition and enabling them to continue with their careers.

- It should be acknowledged that proactive, sound communication and knowledge of the various forms of maternal support (i.e. policies, procedures and processes), as well as the line manager's support, are vital during a woman's maternity transition journey.

- Senior women leaders who are also working mothers could be mentors and role models, and assist and encourage other professional women to help 'normalise' the maternity transition.

\section{Limitations of the study and recommendations for future research}

There are a number of limitations to this study. Although several strategies (such as a researcher's journal) were used to mitigate potential researcher bias and subjectivity, the study cannot be fully detached from the perceptions of the researcher. A further limitation was the small sample of 13 participants that was made up of four different groups for triangulation. All organisational stakeholders who participated in the study were females. Although this was not the intention, it was a challenge to obtain consent from male line managers to participate in the study. As a result, the absence of gender diversity among the participating stakeholders was another limitation.

The following suggestions are offered as areas for future research:

- Investigating the development of a paternal coaching model as a possible support mechanism for parents that includes fathers in the workplace.

- Exploring the longer-term benefits of the Maternity Transition Coaching Model and its impact on the retention of professional women in organisations, given that all the working mothers in this study remained with their respective organisations.

- Further research on the use of the proposed Maternity Transition Coaching Model with its guidelines to better understand its meaningful application in organisations in this niche coaching area.

\section{Conclusion}

The maternity transition process from a working professional woman to a working mother is riddled with internal and external complexities and challenges. The maternity coaching journey had a profound impact on those women participants in the study, not only at a practical level, but also at a psychological and a physical level. The participants perceived maternity transition coaching offered by their organisations to play a key role in assisting them with the transition. In addition, the organisational culture and other maternal support practices during each of the three maternity phases were considered crucial in enabling a positive and successful maternity transition. This study provides a comprehensive understanding and empirical evidence of the complex nature of the maternity transition process for working mothers in organisations. As a result, this study proposes a Maternity Transition Coaching Model underpinned by practical guidelines when introducing a maternity coaching programme as part of an organisation's retention strategy. These guidelines can be applied by human resources personnel, senior management and coaches, who experience the adverse consequences of senior women leaving organisations as a result of maternity transition challenges.

\section{Acknowledgements Competing interests}

The authors have declared that no competing interest exists.

\section{Authors' contributions}

H.M.L.S. was the supervisor for E.B. during the research project and converted the dissertation into the journal article.

\section{Funding information}

The author(s) received no financial support for the research, authorship, and/or publication of this article.

\section{Data availability}

Data that were used in the form of interviews, thematic analysis codes and themes are available upon request.

\section{Disclaimer}

The views and opinions expressed in this article are those of the authors and do not necessarily reflect the official policy or position of any affiliated agency of the authors and the publisher(s).

\section{References}

Ackah, C., \& Heaton, N. (2004). The reality of 'new' careers for men and women. Journal of European Industrial Training, 28(2-4), 141-158, cited in Clarke, M. (2011). Advancing women's careers through leadership development programmes. Employee Relations: The International Journal, 33(5), 498-515. https://doi.org/10.1108/03090590410527582

Anderson, M., Goodman, J., \& Schlossberg, N.K. (2012). Counselling adults in transition: Linking Scholssberg's theory with practice in a diverse world. New York, NY: Springer Publishing Company, Inc. 
Ashforth, B.E., Kreiner, G.E., \& Fugate, M. (2000). All in a day's work: Boundaries and micro role transitions. Academy of Management Review, 25(3), 472-491. https:// micro role transitions. Academy of 15
doi.org/10.5465/amr.2000.3363315

Babbie, E.R., \& Mouton, J. (2006). The practice of social research. London: Oxford University Press.

Beacom, A.M. (2013). The RETAIN maternity leave transition coaching model: Applying Schlossberg's transition theory to create a new model of executive coaching. Doctoral dissertation. Retrieved from ProQuest Dissertations and Thesis database. (UMI 3557142). https://eric.ed.gov/?id=ED552804

Bennett, K. (2017). Living and leading through uncertainty. Randburg: KR Publishing.

Bloomberg, L.D., \& Volpe, M. (2008). Completing your qualitative dissertation: A roadmap from beginning to end. Riverside County, CA: Sage.

Bohrer, A., Cardazone, G., Cooper, M., Coury, S., Huang, J., Krivkovich, A. ...Yee, L (2020). Women in the workplace. Corporate America is at a critical crossroads. McKinsey \& Company. Lean In. Retrieved from https://www.mckinsey.com/ featured-insights/diversity-and-inclusion/women-in-the-workplace

Boz, I., Özçetin, E., \& Teskereci, G. (2018). Becoming a mother after infertility: A theoretical analysis. Psikiyatride Gúncel Yaklasimlar. Current Approaches in Psychiatry, 10(4), 506-521. https://doi.org/10.18863/pgy.382342

Bridges, W. (1980). Transitions: Making sense of life's changes. New York, NY Addison-Wesley.

Brown, L.M. (2010). The relationship between motherhood and professional advancement: Perceptions versus reality. Employee Relations, 32(5), 470-494.

Brown V., \& Hodges N.J. (2016). Appearance and the transition to motherhood: An exploration of identity construction among new mothers. International Textile and Apparel Association Annual Conference Proceedings 73(1), 1-2.

Bussell, J. (2008). Great expectations: Can maternity coaching affect the retention of professional women? International Journal of Evidence Based Coaching and Mentoring, S2, 14-26.

Businesswomen's Association of South Africa (BWASA). (2017). South African women in leadership census 2017. Retrieved from https://bwasa.co.za/wp-content/ uploads/2018/04/2017-BWASA-CENSUS-report.pdf

Cabrera, E. (2007). Opting out and opting in: Understanding the complexities of women's career transitions. Career Development International, 12(3), 218-237. https://doi.org/10.1108/13620430710745872

Cabrera, E. (2009a). Fixing the leaky pipeline: Five ways to retain female talent. People and Strategy, 32(1), 40-45.

Cabrera, E. (2009b). Protean organizations: Reshaping work and careers to retain female talent. Career Development International, 14(2), 186-201. https://doi. org/10.1108/13620430910950773

Cahusac, E., \& Kanji, S. (2014). Giving up: How gendered organizational cultures push mothers out. Gender, Work and Organization, 21(1), 57-69. https://doi. org/10.1111/gwao.12011

Clarke, M. (2011). Advancing women's careers through leadership development programmes. Employee Relations: The International Journal, 33(5), 498-515. https://doi.org/10.1108/01425451111153871

Creswell, J.W. (2009). Research design: Qualitative, quantitative, and mixed-methods approaches (3rd ed.). Thousand Oaks, CA: Sage.

Delport, C.S.L., Fouché, C.B., \& Schurink, W. (2011). Chapter 18: Theory and literature in qualitative research. In A.S. De Vos, H. Strydom, C.B. Fouché, \& C.S.L. Delport (Eds.), Research at grass roots for the social sciences and human service professions (pp. 297-306). 4th ed. Pretoria: Van Schaik Publishers.

Desvaux, G., Devillard-Hoellinger, S., \& Meaney, M.C. (2008, October 3). A business case for women. McKinsey \& Company. Forbes. Retrieved from https://www. forbes.com/2008/10/03/business-women-economics-lead-cx_1003mckinsey. html\#65daOfac2d5d

Eagly, A.H., \& Carli, L.L. (2007). Women and the labyrinth of leadership. Harvard Business Review, 85(9), 63-71.

Ely, R.J., \& Rhode, D.L. (2010). Chapter 14: Women and leadership: Defining the challenges. In N. Nohria and R. Khurana (Eds.), Handbook of leadership theory and practice. New York, NY: Harvard Business Press cited in Skinner, S. (2014). Understanding the importance of gender and leader identity formation in executive coaching for senior women. Coaching: An International Journal of Theory, Research and Practice, 7(2), 102-114. https://doi.org/10.1080/175218 82.2014.915864

Filsinger, C. (2012). How maternity coaching can influence women's re-engagement with their career development: A case study of a maternity coaching programme in UK-based private law firms. International Journal of Evidence Based Coaching \& Mentoring, June(6), 46-56.

Florent-Treacy, E. (2009). Behind the scenes in the identity laboratory: Participants' narratives of identity transition through group coaching in a leadership development programme. International Psychology Review, 4(1), 71-75. https:// doi.org/10.2139/ssrn.1340332

Grady, G., \& McCarthy, A.M. (2008). Work-life integration: Experiences of mid-career professional working mothers. Journal of Managerial Psychology, 23(5), 599-622. https://doi.org/10.1108/02683940810884559

Guion, L.A., Diehl, D.C., \& McDonald, D. (2010). Triangulation: Establishing the validity of qualitative studies. Oxford Express, pp. 22-24. Gainesville, FL: Department of Family, Youth and Community Sciences; Florida Cooperative Extension Service; Institute of Food and Agricultural Sciences; University of Extension
Florida.
Haynes, K. (2008). (Re)figuring accounting and maternal bodies: The gendered embodiment of accounting professionals. Accounting, Organizations and Society, 33(4-5), 328-348. https://doi.org/10.1016/j.aos.2007.04.003

Henning, E., Van Rensburg, W., \& Smit, B. (2004). Finding your way in qualitative research. Pretoria: Van Schaik Publishers.

Hewlett, S.A. (2002). Creating a life: Professional woman and the quest for children. New York, NY: Miramax.

Hewlett, S.A., \& Luce, C.B. (2005). Off-ramps and on-ramps keeping talented women on the road to success. Harvard Business Review, 83(3), 43-54. Retrieved from $\mathrm{https} / / / \mathrm{hbr}$.org/2005/03/off-ramps-and-on-ramps-keeping-talented-women-onthe-road-to-success

Hunt, V., Layton, D., \& Prince, S. (2015). Diversity matters. McKinsey \& Company. Retrieved from https://assets.mckinsey.com/ /media/857F440109AA4D13A54D 9C496D86ED58.ashx

Laney, E.K., Hall, M.E., Anderson, T.L., \& Willingham, M.M. (2015). Becoming a mother: The influence of motherhood on women's identity development. Identity: An International Journal of Theory and Research, 15(2), 126-145.

Lee, R.E. (1984). When mid-career mothers first return to work: Counselling concerns. Journal of Counselling and Development, 63(1), 35-39. https://doi. org/10.1002/j.1556-6676.1984.tb02676.x

Leedy, P.D., \& Ormrod, J.E. (2013). Practical research: Planning and design (10th ed.). New Jersey: Pearson Education, Inc.

Liff, S., \& Ward, K. (2001). Distorted views through the glass ceiling: The construction of women's understandings of promotion and senior management. Gender, Work and Organization, 8(1), 19-36. https://doi.org/10.1111/1468-0432.00120

Liston-Smith, J. (2011). Becoming a parent. In J. Passmore, \& S. Panchal (Eds.), Developmental coaching: Life transitions and generational perspectives (pp. 91-114). London: Routledge.

Ludeman, K. (2009). Coaching with women. In J. Passmore (Ed.), Diversity in coaching: Working with gender, culture, race and age (pp. 237-254). London: Kogan Page.

Mainiero, L.A., \& Sullivan, S.E. (2005). Kaleidoscope careers: An alternate explanation for the 'opt-out' revolution. Academy of Management Executive, 19(1), 106-123. https://doi.org/10.5465/ame.2005.15841962

Matthews, R.A., Winkel, D.E., \& Wayne, J.H. (2014). A longitudinal examination of role overload and work-family conflict: The mediating role of interdomain transitions. Journal of Organisational Behavior, 35(1), 72-91. https://doi.org/10.1002/job.1855

Merriam, S. (1998). Qualitative research and case studies applications in education. San Francisco, CA: Jossey-Bass.

Millward, L. (2006). The transition to motherhood in an organisational context: An interpretative phenomenological analysis. Journal of Occupational and Organisational Psychology, 79(3), 315-333. https://doi.org/10.1348/096317906X110322

Morris, L. (2008). The experiences of women returning to work after maternity leave in the UK: Summary of survey results. Retrieved from http://www.nct.org.uk./ sites/default/files/ReturningToWork-Survey.pdf

Murphy, B.O., \& Zorn, T. (1996). Gendered interaction in professional relationships. In J.T. Wood (Ed.), Gendered relationships (pp. 213-232). Mountain View, CA: Mayfield.

Noon, H., \& Van Nieuwerburgh, C. (2020). Looking forward to going back? The experience of career decision-making for first-time mothers and the implications for coaches. International Journal of Evidence Based Coaching and Mentoring, 18(1), 88-102.

O'Neil, D., \& Bilimoria, D. (2005). Women's career development phases: Idealism, endurance and reinvention. Career Development International, 10(3), 168-189. https://doi.org/10.1108/13620430510598300

Paustian-Underdahl, S.C., Eaton, A.A., Mandeville, A., \& Little, L. M. (2019). Pushed Out or Opting Out? Integrating Perspectives on Gender Differences in Withdrawal Attitudes During Pregnancy. Journal of Applied Psychology, 104(8), 985-1002. https://doi.org/10.1037/apl0000394

Schlossberg, N.K. (1981). A model for analyzing human adaptation to transition (J.M. Whitely, Ed.) The Counselling Psychologist, 9(2), 2-18. https://doi. org/10.1177/001100008100900202

Skinner, S. (2014). Understanding the importance of gender and leader identity formation in executive coaching for senior women. Coaching: An International Journal of Theory, Research and Practice, 7(2), 102-114. https://doi.org/10.1080/ 17521882.2014.915864

Smith, A.N., Morgan, W.B., King, E.B., Hebl, M.R., \& Peddie, C.I. (2012). The ins and outs of diversity management: The effect of authenticity on outsider perceptions and insider behaviours. Journal of Applied Social Psychology, 42(S1), E21-E55. https://doi.org/10.1111/j.1559-1816.2012.01021.x

Smith, J.A. (1999). Identity development during the transition to motherhood: An interpretative phenomenological analysis. Journal of Reproductive and Infant Psychology, 17(3), 281-299. https://doi.org/10.1080/02646839908404595

Smith, R.B., \& Campbell, M. (2010). C-suite challenges and the economic meltdown: What's next for senior leaders? HR People \& Strategy, 33(4), 22-30.

Sparrow, S. (2008, November 18). Keeping mum. Training \& Coaching Today, pp. 18-19.

Spence, G.B., Armour, M.R., Driessen, D., Lea, R., \& North, J. (2016). Contributing to coaching knowledge whilst learning how to research: A review and discussion of four student-coaching studies. Coaching: An International Journal of Theory, Research and Practice, 9(2), 169-184. https://doi.org/10.1080/17521882.2016.1210188 
Still, M.C. (2006). The opt-out revolution in the United States: Implications for modern organizations. Managerial and Decision Economics, 27(2-3), 159-171. https:// doi.org/10.1002/mde.1290

Stout-Rostron, S. (2013). Gender issues in business coaching. In J. Passmore, D.B. Peterson, \& T. Freire (Eds.), The Wiley-Blackwell handbook of the psychology of coaching and mentoring (pp. 155-174). Chichester: Wiley-Blackwell.

Sullivan, S.E., \& Mainiero, L. (2008). Using the Kaleidoscope Career Model to understand the changing patterns of women's careers: Designing HRD programs that attract and retain women. Advances in Developing Human Resources, 10(1), 32-49. https://doi.org/10.1177/1523422307310110

Thornton, G. (2021). Women in business: A window of opportunity. Grant Thornton International. Retrieved from https://www.grantthornton.global/globalassets/1.member-firms/global/insights/women-in-business/grant-thornton-women-inbusiness-2021-report.pdf

Vitzthum, C. (2017). How can maternity-return coaching complement structura organisational benefits? International Journal of Evidence Based Coaching and Mentoring, Special issue (11), 44-56.
Voydanoff, P. (2002). Linkages between the work-family interface and work, family, and individual outcomes: An integrative model. Journal of Family Issues, 23(1) 138-164. https://doi.org/10.1177/0192513X02023001007

Watts, J. (2009). 'Allowed into a man's world' meanings of work-life balance: Perspectives of women civil engineers as 'minority' workers in construction. Gender, Work \& Organisation, 16(1), 37-57. https://doi.org/10.1111/j.1468-0432.2007.00352.x

Williams, J. (2001). Unbending gender: Why work and family conflict and what to do about it. New York, NY: Oxford University Press.

Ye, R., Wang, X.-H., Wendt, J.H., Wu, J., \& Euwma, M.C. (2010). Gender and managerial coaching across cultures: Female managers are coaching more. The Internationa Journal of Human Resource Management, 27(16), 1791-1812. https://doi.org/10 $.1080 / 09585192.2015 .1075570$

Yin, R.K. (2011). Qualitative research design from start to finish. New York, NY: The Guilford Press.

Zimmerman, L.M., \& Clark, M.A (2016). Opting-out and opting-in: a review and agenda for future research, Career Development International, 21(6), 603-633. https://doi.org/10.1108/CDI-10-2015-0137 